\title{
MAKING THE COLONIAL STATE: DEVELOPMENT, DEBT AND WARFARE IN NEW ZEALAND, 1853-76
}

Running title: Making the Colonial State

Dr Bernard Attard

School of Historical Studies

University of Leicester

University Rd

Leicester

LE1 7RH

UNITED KINGDOM

Tel: $+44(0) 1162522798$

Fax: +44 (0)1162523989

Email: BPA1@LE.AC.UK

\section{ACKNOWELDGEMENTS}

The research for this article was substantially funded by ESRC Grant Number R000223775. As well as the ESRC, I would particularly like to thank the Australia and New Zealand Banking Group Limited for granting me access to its outstanding archival collections and for permission to quote from them. I am also deeply indebted to two anonymous reviewers. Responsibility for the approach and content is entirely mine. 


\title{
MAKING THE COLONIAL STATE: DEVELOPMENT, DEBT AND WARFARE IN NEW ZEALAND, 1853-76
}

\author{
Warfare in New Zealand during the 1860 s has recently been linked to the \\ rise of the central state and growth of the national debt in that colony. This \\ article argues that any parallel to the growth of the European fiscal \\ military state is misguided. The fundamental cause of state centralisation \\ and rising indebtedness was the same long-run dynamic of colonial \\ development active in all settler societies during the nineteenth century. \\ The colonial state functioned, in part, to raise capital for development, and \\ if necessary the colonial state would be remodelled in order to achieve \\ this. New Zealand was no exception.
}

JEL categories: F21, F34, H63, N47, O20

Keywords: New Zealand, sovereign debt, colonies, development, settler society. 


\section{INTRODUCTION}

Although many of the country's historians have known better, the idea has started to gain currency that warfare during the $1860 \mathrm{~s}$ 'created the national debt' of New Zealand. ${ }^{1}$ It has been expressed most recently by Mein Smith in her Concise History (quoted here), but can be traced back to Belich's statement in Making Peoples that New Zealand's Wars 'saw the rise of the central state and its alter ego, the national debt'. ${ }^{2}$ The argument has lately been taken up by Ballantyne in his contribution to The New Oxford History of New Zealand. Belich's reference to the national debt is missing, but his nod to the rise of the fiscal-military state becomes explicit: 'Just as the waging of war drove the emergence of powerful centralised states in Europe during the long eighteenth century, the wars of the 1860 s were also an important impetus towards the centralisation of power in New Zealand. ${ }^{3}$ According to this interpretation, the wars were the 'key engine for political transformation'. ${ }^{4}$ The assertion of colonial sovereignty over Maori involved an enormous extension of central power by the General (i.e. colonial) Government. At the same time, it 'shifted influence away from the provinces', which, as the authorities most directly involved

1 Mein Smith, Concise History, p. 70; for the colonial borrowing and debt before 1860, e.g. Morrell, Provincial System, pp. 98, 102; Butlin, Australia and New Zealand Bank, p. 169; Lloyd Prichard, Economic History of New Zealand, p. 71; Gardner, Colonial economy, pp. 64-65.

2 Belich, Making Peoples, p. 242.

3 Ballantyne, State, politics and power, p. 117.

4 Ballantyne, State, politics and power, p. 112. 
in colonisation and public borrowing for that purpose, were important components in the system of government created after $1852 .{ }^{5}$ The ambitious public works policy launched by the colony's treasurer, Julius Vogel, in 1870, completed the process of centralisation. Deprived of their colonising functions, the provinces also lost their reason for existing and were soon abolished. ${ }^{6}$

The significance of the state as a sponsor of economic development in New Zealand and other settler societies has always been recognised. ${ }^{7}$ But if the account just outlined is to be accepted, New Zealand was exceptional amongst British colonial societies, where the extension of central state power and the acquisition of debt were in the first instance closely connected closely connected to processes of colonisation and development. This alternative interpretation of the dynamics of state formation in settler societies is best summarised by Hopkins. 'Seen from an imperial perspective,' he argues, 'Canada, Australia and New Zealand were designed to be developmental states on the British model. ${ }^{8}$ Indeed:

5 Ballantyne, State, politics and power, pp. 112-18; quotes from p. 117; c.f. Sorrenson, Maori and Pakeha, pp. 148-49.

6 C.f. Belich, Making Peoples, p. 242. Belich does, however, acknowledge implicitly the borrowing undertaken for development purposes during the 1860s, as well as the earlier development ambitions of provincial administration, Making Peoples, pp. 351-53.

7 E.g. Bassett, State in New Zealand; Butlin, 'Colonial Socialism'. 8 Hopkins, Back to the future, p. 218. 
In the case of the white empire and other countries dominated by European settlers, such as the Latin American republics, British capital played a major part in creating the state, as well as in promoting agricultural and mineral exports. Without a state there could be no public guarantee of debt service and therefore no prospect of sizeable public foreign borrowing; without inflows of capital, principally from London, development prospects were limited. ${ }^{9}$

By contrast, while the recent interpretation of New Zealand state formation gives due weight to the public works policy of the 1870 s, it views this as part of a subsequent stage, while the question of the colony's credit is treated as unproblematic. ${ }^{10}$

There is no disagreement here that the warfare between the settlers and Maori, and all the consequences that flowed from it, contributed in important ways to the rise of the central state and the growth of the national debt during the 1860 s. But this article does suggest that it is at best a partial explanation. Rather, it follows Hopkins in arguing that the underlying force driving state formation and the accumulation of government debt in the long-run was the same dynamic of colonial occupation and economic development that was active in all regions of recent settlement at the time, and which Belich himself has written about so vividly in his recent work on the 'settler revolution' (to which we will return shortly). ${ }^{11}$ This dynamic explains why the colonists had already started to borrow during the 1850s; by stimulating settler

9 Hopkins, Back to the future, p. 233.

10 Ballantyne, State, politics and power, pp. 117-18; c.f. McAloon, New Zealand economy, p. 209.

11 Belich, Replenishing the Earth. 
demand for land ('land hunting' as one historian tellingly describes it), the same dynamic was also 'a potent cause of war', even if not the only one. ${ }^{12}$ The outcome of the fighting between Maori and colonisers in the North Island-as well as the long history of occupation since 1840 — thus became another example of how 'Britain's generosity in giving settlers other people's land ... was the basis of the colonial economy. ${ }^{13}$ Finally, by also creating a demand for British capital which could only be satisfied by control of the public credit by a single borrower, the dynamic of settler developmentalism inevitably led to the centralisation of state power itself. ${ }^{14}$

Thus, in New Zealand, as in other regions of European settlement separated as widely as Canada and the Argentine, the developmental imperative from the midnineteenth century was linked to the rise of indebtedness and the consolidation of state powers. ${ }^{15}$ New Zealand was one part of the larger 'settler revolution' and there is no need to invoke parallels with the rise of the fiscal-military state (which, in any event, was already an accomplished fact) to explain these events. Moreover, even before the

12 Hawke, Making of New Zealand, p. 23 (for quote); Weaver, Frontier into assets (for 'land hunting'); Gardner, Colonial economy, p. 65; Sorrenson, Maori and Pakeha, pp. 148-49.

13 Hopkins, Back to the future, p. 218.

14 Some of this argument from the British perspective has already been developed in the context of a broader discussion of 'informal imperialism' and 'gentlemanly capitalism' in Attard, Free-trade Imperialism.

15 E.g. Platt and Adelman, London merchant bankers, pp. 224-25; Cortes Condé, Political Economy of Argentina, pp. 2, 18; Marichal, Century of Debt Crises, pp. $164-67$. 
growth of a substantial staple export sector, some form of 're-colonisation' (to use Belich's terminology) - i.e. integration with economies in the 'oldlands' of Western Europe and the eastern United States — was inevitable as soon as settlers on distant frontiers involved themselves in metropolitan capital markets. ${ }^{16}$ This, as the example of New Zealand shows, occurred remarkably soon after the colonists became selfgoverning. It was no coincidence that borrowing for developmental purposes also quickly came to be seen as a key function of the colonial state itself.

Despite the qualification just made, it should already be evident that the argument about state formation outlined here broadly complements Belich's account of the 'settler revolution', which extends to the entire 'Anglo-world' an interpretation of the colonisation process first applied to New Zealand in his earlier domestic histories. ${ }^{17}$ By doing so, Belich himself firmly reinstates settler developmentalism ('growth through growth'), expressed in the ideology of 'settlerism', as the core dynamic in New Zealand's history from as early as 1850 , when 'the economy's main game was growth itself' ${ }^{18}$ The entire process of Anglophone colonisation in the temperate latitudes is conceived as a recurrent developmental cycle which, in its

16 Belich, Replenishing the Earth, pp. 179-80.

17 Belich, Replenishing the Earth; c.f. Belich, Making Peoples, pp. 349-51 and Belich, Paradise Reforged, pp. 29-30, 77, 85-86, where 'progressive colonisation' covers both the 'incremental' and 'explosive' phases in the fully worked out version of the argument.

18 Belich, 'Cloning Britain' (quote from p. 249); Belich, Replenishing the Earth, pp. $87,153-65$. Belich identifies two variants of 'settlerism'; the formal version is the most relevant here. 
'explosive' (or boom) phases drew in vast amounts of people and capital. ${ }^{19}$ The boom-related borrowings of New Zealand's provinces during the 1860s (as distinct from war-related debt) are now brought back into the picture, while the settler juggernaut as much as warfare is shown to have 'swamped and marginalized Maori': 'It was explosive colonization that proved too much for them.' Even the creation of larger political structures in Canada, Australia and (by implication) New Zealand are tentatively linked to the need to improve colonial credit and thus 'prime the pump of explosive colonization'. ${ }^{20}$

Ironically, by questioning one interpretation of the process of state formation that persists through transmission, this article confirms Belich's latest intuitions about the dynamics of the same process when considering the settler revolution writ large. By contrast, however, it emphasises the external agency of formal imperial authority and (more powerfully) metropolitan capital markets, and argues that often the pressures to establish strong state structures to underwrite the servicing and ultimate repayment of debts existed even before a settler boom could properly get underway. ${ }^{21}$ For this reason, as already suggested, 'explosive colonisation' is often not as easily unscrambled from 're-colonisation' as Belich would have us believe.

19 Belich, Replenishing the Earth, pp. 86-87.

21 This argument needs refining, but we can think of the main investment booms in New Zealand (1870s), Australia (1880s) and Canada and Argentina (post-1900). The extent to which the state continued to facilitate capital inflows after an initial 'boom' is also an important factor. 
The rest of this article is in three parts. The first considers the relationship between development, debt and state formation in New Zealand from the mid-1850s to 1861 , when the British guarantee of a colonial loan first raised questions about the suitability of the colony's provinces as borrowing agencies. It thus also offers a history of the origins of New Zealand's public debt, with quantitative estimates, that is missing from the modern literature as well as New Zealand's official statistics. The second analyses the same relationship between development, debt and state formation from 1862 to 1876 . At the beginning of the period 'explosive colonisation' in the South Island as much as warfare in the North caused the settlers to seek unprecedented sums from the London capital market; at its end, the provinces-which had been the vehicles for this often abortive borrowing - were abolished. Finally, the concluding section briefly recapitulates the argument, suggesting that the greatest impact of New Zealand's Wars was as a catalyst accelerating a centralisation of the state that had already become inevitable.

\section{DEVELOPMENT, PROVINCIAL DEBT AND THE GUARANTEED LOAN}

The devolution of government throughout the British settler world during the 1840 s and 1850s was followed almost immediately by the beginning of large-scale public borrowing by the colonists themselves. Settler polities immediately assumed the character of 'developmental states'. Free of direct imperial supervision, they raised capital on the strength of their own credit to cover immigration expenses and create the essential infrastructures of colonial society. ${ }^{22}$ This surge in the settler demand for

\footnotetext{
22 Cain and Hopkins, British Imperialism, ch. 8.
} 
capital was a small part of a global phenomenon. Although the latter's origins can be traced to earlier decades, foreign (including colonial) investment by Britain and France accelerated during the 1850s. The outflow was associated, above all, with the diffusion of new transport technologies and the recognition by entrepreneurs, speculators and rentiers of the investment opportunities created by an expanding world economy, including, of course, the land and other natural resources of the temperate 'newlands' in both hemispheres. ${ }^{23}$

It would be odd indeed if New Zealand's colonists were unaffected by these developments. They too started to borrow almost as soon as they became selfgoverning in January 1853. But the precise purposes, forms, agencies employed, and distribution of costs were influenced by three factors. First, the colonists started with a substantial debt to the New Zealand Company for land in the South Island that had been returned to the Crown after the Company surrendered its charter in $1850 .^{24}$ Second, when the British originally imposed their sovereignty in 1840 they recognised Maori ownership of land at the same time as they asserted the Crown's pre-emptive right to purchase it. The actual process of land transfer to settlers (particularly pastoralists) had often been beyond formal control, or was carried out by

23 The growth of international investment before 1870 is widely documented, e.g. Cassis, Capitals of Capital; Cottrell, British Overseas Investment; Jenks, Migration of British Capital; Piva, The Borrowing Process; Wilkins, Foreign Investment.

24 Lloyd Pritchard, Economic History, pp. 52, 55; Morrell, Provincial System, pp. $57-58,69$. 
imperial authority at enormous disadvantage to Maori. ${ }^{25}$ Native title, however, meant that land could not be treated as an entirely free good, nor-where it had not already been alienated (effectively in the North Island) — was its price immune from market forces. $^{26}$ Thus, after 1852, while the colonial state performed its typical function of regulating the terms of British settlement, it also had to mobilise the resources to finance land purchases. Finally, New Zealand's Constitution of 1852 and its early application by the colony's governor led to the emergence a highly decentralised system of government which reflected the isolated circumstances of the several British settlements. ${ }^{27}$ The seat of the General Government was initially located in Auckland in the North Island (it was transferred to Wellington in 1865), but the colony was divided into six provinces (later increased to ten) which immediately took responsibility for immigration and the delivery of basic services. ${ }^{28}$ The provincial administrations each consisted of a superintendent and an elected council, but they

25 Gardner, Colonial economy, pp. 58-59; Sorrenson, Māori and Pakeha, pp. 14748; Parsonson, Mana Māori, pp. 178-79; Weaver, Land into assets.

26 The 'enhanced value of land ... in the estimation of the Natives' became one argument why the Imperial Government should guarantee a loan to pay for future purchases; New Zealand, Parliament (NZ), Appendix to the Journals of the House of Representatives (AJHR), B-5, 1858, p. 14, Memorandum from Mr Sewell, 8 May 1857.

27 The standard history remains Morrell, Provincial System, which is used extensively here.

28 Morrell, Provincial System, p. 92; Dalziel, Politics of settlement, p. 99. 
had no separate powers under the constitution and their finances were entirely in the gift of the General Government.

From the beginning of self-government, therefore, the colonists needed to finance past as well as future transactions in land ('pure' Wakefieldian investment, if you will), in addition to the 'complex of activities involving growth and development' associated with rapid colonisation. ${ }^{29}$ The exact division of responsibilities was determined by the 'Compact of 1856 ', the financial arrangements inaugurated by Edward Stafford's ministry in July that year. ${ }^{30}$ Land administration and the revenues arising from land sales and rents were transferred to the provinces. The land fund itself was 'to be dedicated to Public Works, Immigration, and other local purposes, giving value to the waste lands from the sale of which it is derived'. ${ }^{31}$ Thus the provinces were confirmed in their functions as the colony's principal development agencies. Provincial finances were further underpinned by at least three-eighths of the colony's gross customs receipts, a transfer which was probably not first envisaged as being permanent but effectively became so. In addition, the General Government undertook to raise a long-term loan for half a million sterling, of which $£ 200,000$ would be used to pay off the New Zealand Company, $£ 180,000$ to purchase land for settlement in the North Island, and the balance for the General Government's own purposes, including other land payments and the retirement of a small debenture

Belich, Replenishing the Earth, p. 87; Attard, Wakefieldian investment.

30 For this and the rest of the paragraph: United Kingdom, Resolution; Morrell, Provincial System, pp. 91-101; Gardner, Colonial economy, pp. 64-65.

31 Quoted in Morrell, Provincial System, p. 98 
dating from the crown colony period. ${ }^{32}$ The provinces would be the direct beneficiaries of the first two portions of the loan through the transfer of the territorial (i.e. land) revenues. The costs - some $£ 22,800$, including contributions to the sinking fund, when the loan was fully issued - were therefore made a first charge on them and would be unavailable for other provincial expenditures. A quasi-federal system was thus created in the colony, but part of the provinces' income had already been hypothecated and the provincial share of customs depended entirely on the pleasure of the central government.

\section{[INSERT FIGURE 1 ABOUT HERE]}

\section{[INSERT FIGURE 2 ABOUT HERE]}

The Union Bank of Australia offered the first part of the half million loan-a tranche of $£ 200,000$ — in London under guarantee of the British Treasury in July 1858 (Figure 1). ${ }^{33}$ Some of the receipts were anticipated by sales of short-dated securities in eastern Australia and in the colony itself. ${ }^{34}$ In fact, neither issue was the first New Zealand public loan to appear in London or Australasia. Following established colonial practice, the provinces were already using the land fund to subsidise

32 For the debts taken over in 1853 by the new colonial government: NZ, Votes and Proceedings, 1854.

33 Attard, Database.

34 Simmonds, Fenn's Compendium, p. 186. 
immigration and pay for local public works. ${ }^{35}$ The uncertainty over land policy in the mid-1850s, however, depressed sales, while land scarcity meant that income in the North Island would always be limited (Figure 2). Borrowing allowed the provinces to anticipate or supplement their revenues. As early as December 1854, Isaac Featherstone, the Superintendent in Wellington, assured the Provincial Council that any shortfall in funds available for the construction of roads and a pilot station would 'be readily met by the sale of the requisite number of debentures'. ${ }^{36}$ The following March, William Brown in Auckland, reminding council members of 'the want of roads for conveying produce to market and for facilitating intercourse', proposed to cover a deficit of almost $£ 7,000$ by similar means. ${ }^{37}$ In doing so, Brown-a Scot who had made a successful career in the North Island as a partner in the merchant house Brown \& Campbell—articulated a rationale for public borrowing for developmental purposes in new colonies which soon became commonplace:

The Province has a sure, a large, and an increasing revenue; but from the source of revenue alone, too long a period would elapse before acquiring a surplus large enough to carry out permanent improvements. By borrowing money, alone

35 Hensley, Canterbury, p. 29; Burroughs, Britain and Australia; Piva, Borrowing Process.

36 The National Archives of the UK (TNA): Public Record Office (PRO)

CO 209/135, f. 135, Address by Superintendent, Journal of Provincial Council, 21 December 1854, p. 11.

37 TNA: PRO CO 209/136, f. 206, Speech delivered by the Superintendent, 26 March 1855, Messages of the Provincial Council, May 1855, p. 3. 
can we make fair and reasonable provision for the vast and expensive undertakings required in a new country. And it is only fair and reasonable, as it is consistent with sound policy, that posterity should pay a share of the expense which we are now incurring in making the country for future generations. If the invention and labour fall on us, let a portion at least of the expense be entailed on them. ${ }^{38}$

By the end of 1856 , at least $£ 165,500$ of debt had been authorised by provincial councils. A year later, that figure had grown by as much as half again. ${ }^{39}$

Small amounts could be raised in eastern Australia or even the colony itself, but ultimately most of the money came from England or Scotland, more often than not from investors who already had some commercial interest in, or other experience of, the Australasian colonies. ${ }^{40}$ The loans themselves were too small and the borrowers too obscure to create a market in the United Kingdom. Surveying the mixed results of the Union Bank's public offer of Wellington debentures in July 1857 (the first of its kind in the City of London by any Australasian borrower), the Bank's Secretary

38 TNA: PRO CO 209/136, f. 208; Stone, Brown; for the same rationale expressed in the 1870s, Bassett, State in New Zealand, p. 58.

39 NZ, AJHR, B-7, 1863; this excludes the $£ 10,000$ sold in Auckland in October 1855, TNA: PRO CO 209/135, f. 136, Auckland Provincial Government Gazette, 9 Nov 1855.

40 The details cannot be provided here, but see for an example the list of tenders for a Wellington loan in: Australia \& New Zealand Banking Group Limited, Group Archive, Melbourne (ANZ): U/7/5, 10 July 1857. 
remarked apologetically to Featherstone, the Superintendent, on 'the slight knowledge possessed by capitalists of the position of your important Province', and could only offer mixed assurances that 'this beginning may prove of importance in creating a market for the Provincial securities'. ${ }^{41}$

By then, however, the opportunities for further borrowing by Wellington, or any other province for that matter, had been severely curtailed. Earlier in 1857, the colony asked the imperial government to guarantee the half million loan to be raised under the terms of the Compact. The British had originally offered to guarantee a much smaller issue to clear the colonists' debt to the New Zealand Company. In the event, they were persuaded to cover the entire half million. ${ }^{42}$ As a result, however, the Exchequer acquired a material interest in ensuring that the colonists remained sufficiently solvent to continue servicing the loan. The colony's Governor, Colonel Thomas Gore Browne, a career soldier who nevertheless clearly understood the principles of public finance in a new colony, was the first to see the implications of the proposed guarantee. In February, he warned the Premier, Edward Stafford, of the effect Featherston's latest borrowing proposals might have on the security of the half million loan as a result of the additional burden imposed on the land fund by rising debt charges. Gore Browne himself sympathised with the colonists' developmental aspirations: 'Money judiciously expended must tend to hasten and encourage the prosperity of the locality where it is expended, more especially in a new Colony

41 ANZ: U/120/8, Saunders to Superintendent Wellington, 16 July 1857.

42 Morrell, Provincial System, pp. 98-99; Attard, Free-trade imperialism, pp. 50910. 
where it is much more fruitful than in old countries'; but he did not assume that provincial leaders would always be able to administer public funds 'wisely'. ${ }^{43}$

At first, Stafford refused either to accept any General government liability for provincial debt or to acknowledge that new provincial borrowing might affect the security of the guaranteed loan. ${ }^{44}$ By May, however, he had been persuaded, or simply changed his mind. A circular was issued to the Superintendents instructing them to seek the General government's approval for any further provincial borrowing. ${ }^{45}$ It was, as Morrell noted a long time ago, 'the first important use of the controlling power given by the Constitution'. ${ }^{46}$ Moreover, when the Imperial authorities were alerted by Gore Browne, they too imposed their own restrictions as a condition of the Exchequer guarantee. These were a more stringent version of the instructions Stafford had already issued: all provincial loan ordinances would have to be reserved for the Governor's assent, which could only been given if the proposed borrowings were minor and could be shown to be essential; otherwise, any province wishing to raise 'loans to any serious amount' would first have to produce resolutions for consideration in London before any legislation could be contemplated in the colony. $^{47}$

The regulations proved remarkably effective. Apart from the Canterbury loan ordinance which will be discussed below, until Stafford's resignation in July 1861,

43 TNA: PRO CO 209/141, f. 133, minute Gore Browne, 2 February 1857.

44 TNA: PRO CO 209/141, ff. 136-37, Stafford, 5 February, 1857.

45 Morrell, Provincial System, p. 102.

46 Morrell, Provincial System, p. 102.

47 NZ, AJHR, B-5, 1858, pp. 17-18, Labouchere to Gore Browne, 15 Sept 1857. 
Gore Browne was asked to assent to only four small provincial issues authorising new borrowings of just under $£ 71,000 .{ }^{48}$ Repeated disallowance of other provincial ordinances kept the total low. The colonists in Otago waited two and a half years before finally obtaining approval for a small migration loan only to find that the gold discoveries at Tuapeka in May 1861 made the notion of assisted immigration entirely redundant. ${ }^{49}$ As a result of the General Government's parsimony, there was only a minor increase in the number of provincial bonds in circulation after 1858 (see Appendix I), and the growth of the public debt was halted almost entirely (Figure 3).

\section{[INSERT FIGURE 3 ABOUT HERE]}

Even Gore Browne's assent in 1860 to a Canterbury ordinance authorising a loan for the unprecedented sum of $£ 300,000$ was the exception that tested, but did not break, the rule. By the late 1850s, Canterbury was the most prosperous province in the colony. ${ }^{50}$ The pastoral expansion following the final settlement of land policy in 1856 created conditions for a dramatic, if unstable, increase of territorial revenues (Figure 2). These in turn provided the means for further public works and assisted migration

49 Otago, Appendix to Votes \& Proceedings, Correspondence respecting loan (some dates have been misprinted); Otago Witness, 29 Jan 1859, p. 5; 6 Oct 1860, p. 5; 22 June 1861 , p. $2 ; 29$ June 1861, p. 3; 26 Oct 1861, p. 5; 28 Oct 1861, p. 9. 
to sustain the expansion. ${ }^{51}$ The ambitions of William Moorhouse, the Superintendent from 1857, eventually extended to considering a scheme for a local railway system at an estimated cost $£ 1.5$ of million, but his immediate plan was to drive a railway tunnel through the side of the extinct volcano separating Christchurch from its harbour at Lyttelton, some twelve kilometres away. ${ }^{52}$ It would be the first steam railway project in New Zealand, and given the requirement for all major borrowing proposals to be referred back to London, lobbying for approval took place in Whitehall as well as the colony.

In 1858 , the province's emigration agent, James FitzGerald (who had an alternative proposal) asked the Colonial Office to give the Governor discretion to consent to a $£ 70,000$ loan without first having to consult London. ${ }^{53}$ A year later, FitzGerald was instructed to make the same request for a $£ 200,000$ loan to finance Moorhouse's original tunnel scheme. ${ }^{54}$ Henry Herbert, the fourth Earl of Carnarvon and a young Under Secretary of State in Derby's Conservative ministry, wrote a lengthy response to FitzGerald's original enquiry which effectively became British policy on the matter. Carnarvon was a careful steward of his own estates who later invested in colonial land and securities. In economics, at least, he was attuned to the colonists' improving instincts. ${ }^{55} \mathrm{He}$ acknowledged that the Exchequer guarantee

51 Simkin, Dependent Economy, pp. 121-22, 126; Morrell, Provincial System, pp. 104-6; Hensley, Canterbury, 1853-7, p. 61.

52 Scotter, Canterbury, pp. 84-89.

53 TNA: PRO CO 209/149, ff. 286-88, Letter from FitzGerald, 12 Nov 1858.

54 TNA: PRO CO 209/152, ff. 566-57, FitzGerald to Newcastle, 4 Oct 1859.

55 Adonis, Survival of the great estates; Briggs, Age of Improvement, pp. 2-3. 
indeed did mean that 'a definite Imperial interest mixes itself up with the question', as well as the risk of creating a precedent for the other provinces. ${ }^{56}$ Yet, self-evidently, the development of the imperial estate was a worthwhile and necessary goal, and Carnarvon had no doubts - like Superintendent Brown in Auckland - that large-scale investments by the colony's public authorities were essential:

It is probable that the construction of a railway as proposed would prove very beneficial to the commerce of the province and perhaps w[oul]d so largely increase the traffic that the original cost $\mathrm{w}[\mathrm{oul}] \mathrm{d}$ soon be repaid. But over \& beyond this it is clear that any great development of Colonial trade \& production will be, to say the least, stimulated \& quickened by the construction of railroads if carried out at a reasonable expenditure: and unless private companies undertake the work, which is improbable in $\mathrm{N}[\mathrm{ew}]$ Zealand under present circumstances, that work will have to be done by means of a loan. Therefore to refuse consent to the raising of a loan for the construction of railways, or to say that the home Gov[ernmen]t will not consent to it until there is a superfluity from the current expenditure of the year sufficient to cover the cost of construction is practically to prohibit or to retard to an indefinite period any line of railway. ${ }^{57}$

\footnotetext{
56 TNA: PRO CO 209/149, f. 290, C[arnarvon], 18 Nov 1858; c.f. f. 292, G. B. L[ytton], 26 Nov [1858]; and CO 209/152, f. 569, T. F. E[1liot], 4 Oct [1859]. 57 TNA: PRO CO 209/149, f. 290, C[arnarvon], 18 Nov 1858.
} 
For the same reasons, a year later, one senior official commented: 'There cannot but be a wish to allow the colonists every facility for making their railway which can be granted without creating any undue risk of demands on the British Exchequer. ${ }^{58}$ The Treasury insisted that the Governor should still refer back to London if he had any doubts about 'the necessity and expediency of the intended work, and that the security of the Guaranteed Loan will not be affected thereby'. ${ }^{59}$ Yet save for this, both Bulwer Lytton, the Conservative Secretary of State, and his Liberal successor, Newcastle, were happy to leave the decision to Gore Browne and his ministers. ${ }^{60}$

As far as the colony's authorities were concerned what mattered most that the provinces continued to live within their means. Stafford acknowledged the importance of improving communications in Canterbury, the appropriateness of the railway proposal, and the 'special necessity for a work of this character and magnitude' ${ }^{61}$ But he was still adamant that any loan could only be sanctioned as an 'exception to the general rule which would influence the Government to check the tendency observable for some time in many of the Provinces to accumulate public debts'. The Premier also thought that a loan might be 'raised on the credit of the Colony', i.e. that borrowing for the provinces could be undertaken by the General Government itself. ${ }^{62}$ For his part, Gore Browne admitted 'the advantages of the railway', but doubted that the

58 TNA: PRO CO 209/152, f. 569, T. F. E[1liot], 4 Oct [1859].

59 TNA: PRO CO 209/148, ff. 510-11, Trevelyan to Merivale, 11 Dec 1858.

60 TNA: PRO CO 209/149, f. 292, G. B. L[ytton], 26 Nov [1858]; PRO CO 209/152, f. 570, N[ewcastle], 9 [Oct 1859].

61 TNA: PRO CO 209/153, f. 246, Stafford to Superintendent, 25 Feb 1860.

62 TNA: PRO CO 209/153, f. 247, Stafford to Superintendent, 25 Feb 1860. 
province would have enough money to complete the railway tunnel (which Moorhouse wanted to fund partly from revenue). He was also still 'quite certain that the control of a central Gov[ernmen]t is absolutely necessary to prevent reckless financial mismanagement. ${ }^{, 63}$ He proposed instead that the entire project be financed by a loan for $£ 300,000$, which could only be raised in annual sums of $£ 50,000$ when the province could show it was capable of covering the charges for each additional instalment. $^{64}$

Finally, in late 1860 - two years after the province's original approach to the Colonial Office - Stafford and the Governor agreed to a loan on these terms. ${ }^{65}$ The amount of potential borrowing by a single province had been increased enormously; its essential development objectives were acknowledged and endorsed in both London and the colony, but the rate at which capital could be raised was still tightly controlled by the central government. Long before the Otago gold discoveries, however, the pressure to accelerate public investment in the more prosperous parts of the colony was rising.

Appendix I presents statistics of New Zealand's public debt from 1853 to 1861 , the year prior to the inclusion of the first statement of public debt in the colony's official statistical year book. The table is divided into two panels, showing respectively the annual nominal value of outstanding General government and provincial securities. The totals of General government debt are for 1 September and

\footnotetext{
63 TNA: PRO CO 209/153, ff. 198-9, Gore Browne to Gairdner, 27 Jan 1860.

64 TNA: PRO CO 209/153, ff. 207-8, Governor to Ministers, 24 Jan 1860.

65 Lyttelton Times, 28 March 1860, p. 4; 24 Oct 1860, p. 4; TNA: PRO CO 209/157, ff. 445-46, Gore Browne to Newcastle, no. 144, 31 Dec 1860.
} 
taken mostly from the colony's annual financial statements and accounts. The totals of provincial debt are for 31 December and derived from the records of known issues and sales. Detailed notes about the sources and assumptions used to construct the estimates are given in the appendix. The figures for debt held in the United Kingdom are estimated minimum sums and make no allowance for the remittance of securities originally sold in the colonies.

Three points can be made. First, the total colonial debt of just under $£ 900,000$ at the end of 1861 had already been augmented by 'the War Loan of 1860', a General government issue for $£ 150,000$ (see section 2 below). ${ }^{66}$ The impact of this on the overall growth of the debt, however, was more than offset by the loan for the Lyttleton and Christchurch railway, none of which had yet been sold. Second, the 'national debt' of New Zealand, like that of the other Australasian colonies, was a creation of the $1850 \mathrm{~s}$, but it was still essentially a provincial one. Of the $£ 450,000$ of the guaranteed loan outstanding, almost two-thirds were being charged to the provinces. When the provinces' own debentures are added, 64 per cent of the colony's total indebtedness was provincial. ${ }^{67}$ Finally, after a flurry of small loans authorised by provincial councils before the imposition of central control in 1857, the growth of new provincial debt slowed dramatically. This is illustrated even more clearly in Figure 3.

66 The colonial treasurer's description in his Finance Statement for 1863, re-printed in United Kingdom, Correspondence, p. 254.

$67 £ 292,000$ of the guaranteed loan was charged against the land revenue in June 1861, NZ, AJHR, B-1, 1862, p. 9. 
Given their own financial instability, the demands of the guaranteed loan, and the pressures to continue promoting settlement, it was inevitable that the provinces would soon come to the limit of their borrowing powers. This was not for want of sympathy with the colonists' developmental ambitions in Westminster and Whitehall. The imperial guarantee, however, had exposed the weaknesses of provincial credit, for as Carnarvon shrewdly observed: 'in proportion as the indebtedness of the parts is increased the security \& solvency of the whole is imperilled' ${ }^{68}$ The Exchequer's desire to protect the security of the guaranteed loan thus induced the first important centralisation of state power in the colony: control of provincial borrowing by the General Government under imperial supervision. For this reason it is possible to argue that British capital during the 1850 s was already 'creating the state' in settler society. ${ }^{69}$ The circumstances in New Zealand - the request for, and granting of, the guarantee- were unusual, but the imperial Exchequer's logic was the essentially the same as the market's: new debt ought not to be acquired unless the security (and, by implication, the security of existing debts) was certain.

As it happened, the South Island's boom from the late 1850s quickly dispelled most of the Colonial Office's fears. Yet, when the provinces next attempted to borrow in London on any scale, their underlying weaknesses as investment agencies were again exposed. New Zealand's colonists learnt the same lesson as others in the settler world: buoyant expectations did not necessarily mean that capital would be supplied on any terms. The pace of colonial expansion would ultimately always be subject to metropolitan control.

TNA: PRO CO 209/149, f. 290, C[arnarvon], 18 November 1858.

69 Hopkins, Back to the future, p. 233. 


\section{DEVELOPMENT, CREDIT AND THE ABOLITION OF THE PROVINCES}

It has been convenient so far to consider the origin of New Zealand's public debt in a single period to the end of 1861 , but it is clear enough that the colony's circumstances were starting to change well before then. From the late-fifties, Canterbury's prosperous colonists successfully sought imperial approval for the most ambitious capital project yet attempted in the colony. The General Government had also borrowed to cover the direct and related expenses of the fighting in Taranaki during 1860-61, the first of the settlers' 'wars' with Maori in that decade. For the rest of the sixties, development expenditures and war-related costs would both add enormously to the national debt. Between 1862 and 1868, this grew more than seven-fold to just over seven millions (see Appendix II). Almost half the increase was accounted for by the General Government's loan for three millions, the rest by the provinces, whose development ambitions in the South Island remained the principal motive for public borrowing. The General Government eventually found all the money it needed, but the provinces' issues again raised fundamental questions about their creditworthiness. Unable to borrow, they were also unable to function as developmental agencies. The only alternative was to centralise control of the public credit with consequences for the entire structure of government in New Zealand.

After the Otago gold discoveries in May 1861, economic expansion in the South Island turned into a boom that propelled both that province and neighbouring Canterbury into their brief epochs of 'explosive colonisation' ${ }^{70}$ Starting from an admittedly small base, in the four years to 1864 the population of Otago more than

70 As defined in Belich, Replenishing the Earth, pp. 86, 178-79. 
quadrupled to almost 58,000. Canterbury's doubled in the same period. ${ }^{71}$ The gold boom strained Otago's infrastructure and finances to near breaking point, and the Provincial Council quickly asked for permission to borrow for harbour works, public buildings and 'the expenses of the gold fields'. ${ }^{72}$ The boom rapidly spread to Canterbury, where the colonists contemplated even more ambitious infrastructure projects. In June 1861, when the gold findings at Tuapeka had only just become known, the Union Bank's Australasian manager in Melbourne agreed to take on the agency of Canterbury’s $£ 300,000$ loan, assuring his directors in London that the Lyttelton and Christchurch railway was 'absolutely necessary to the full development of the resources of the Province' ${ }^{73}$ In November 1862, 'dazzled ... with the prospect of rapid provincial development', the Council agreed to borrow another half million for railways and other capital works. ${ }^{74}$

Soon one of Canterbury's elder statesmen, Henry Sewell, was regretting 'the Moorhouse policy', which had 'beguiled the whole Colony into following his example'. ${ }^{75}$ In Otago, Superintendent Richardson, observing 'that several of the provinces have, or contemplate having, large powers of raising money', immediately asked the General Government for approval to raise half a million for roads and the

71 Even without Westland, Canterbury's annual rate of population growth of 5.7 per cent to the end of the decade was respectable, if not 'explosive'. Pritchard, Economic History, tables 28 and 47.

Otago Witness, 2 November 1861, p. 9.

ANZ: U/103/2, McMullan to Cummins, no. 152, 25 June 1861.

Scotter, Canterbury, pp. 100-1.

Journal, 10 May 1863, quoted in Morrell, Provincial System, p. 140. 
employment of redundant miners; the new province of Southland required equal access to the Otago diggings and a better connection to its own port; Nelson floated schemes to build tramways and railroads to potential coal fields. ${ }^{76}$ In the North Island, land settlement was as important as public works, but the intention to pay for both by public borrowing was the same. Between the fall of the Stafford ministry in July 1861 and the middle of 1863 , just under $£ 2$ millions of new provincial debt were sanctioned by the General Government. When the Lyttelton and Christchurch loan (little of which had yet been offered to investors) and further provincial authorisations in the next twelve months were added, the total was closer to two and a half millions. ${ }^{77}$

There are several explanations for this sudden loosening of policy. Stafford's ministry had fallen because of the political reaction against its centralising policies. Inevitably, its successors were more sympathetic to provincial aspirations. ${ }^{78}$ Shortly after, Gore Browne was replaced by Sir George Grey, who, following the precedent of the Lyttelton and Christchurch railway, acted as if he now had discretion to assent to any provincial proposals without needing to refer back to London. But, above all, two reasons stood out. The most obvious was the economic boom itself, which added enormously to the revenues of the South Island provinces (Figure 2) at the same time as it strengthened their case for new capital works. Rising land values and the 'very flourishing condition' of public revenues meant the imperial government no longer

for the other provinces, see this source and Morrell, Provincial System, pp. 13940.

77 NZ, AJHR, 1868, B-6.

78 Morrell, Provincial System, pp. 115-21 
had to worry about the security of the guaranteed loan. ${ }^{79}$ When informed by Grey of the new Canterbury loan ordinance, the Colonial Office's officials could only express wonderment at the speed of growth in the province: ' 13 years ago the Settlement of Canterbury had not started into life. It is now a separate Province with a Revenue of over $£ 250,000$ a year, \& they are borrowing $£ 500,000$ for more rapidly developing its resources, \& at 6 per Cent interest.' Their only real interest in the matter was that the new provincial loan ordinances should still formally recognise the priority of the charges for the guaranteed loan. ${ }^{80}$

In the North Island, by contrast, the colonists' desire to consolidate British settlement in the aftermath of the Taranaki fighting was uppermost. When in March 1863 Auckland proposed to issue a half million loan, the colonial Treasurer doubted whether it was prudent, yet told the Superintendent:

But looking at the present position of the Province in other respects, and having regard to the pressing necessity that exists in reference to the Native question to introduce immigrants into the Province of Auckland, and to provide funds for the purchase of sufficient lands for their location, the political necessity outweighs mere financial considerations. ${ }^{81}$

Governor Grey even referred to 'the Native Question' when justifying to the Colonial Office his assent to the second Canterbury railway loan, although he only mentioned

80 TNA: PRO CO 209/172, ff. 144-45, G. G[airdner] to Elliot, 17 May 1863.

81 NZ AJHR, B-5, 1863, p. 3, Wood to Superintendent, 16 April 1863. 
it after noting the province's 'remarkable advances in wealth and population' ${ }^{82}$ It may simply have been another excuse not consulting London.

But whatever the impact of the New Zealand Wars on the resurgence of provincial borrowing, the most obvious way in which they affected the national debt was directly through the General Government's own borrowings. The small 'War Loan' of 1860 - 'to meet the charges of providing arms for the Militia, and executing some necessary public works, especially a central prison and a general lunatic asylum'- has already been mentioned. ${ }^{83}$ In 1862, the Assembly authorised another half million loan to reimburse the British Exchequer for the expenses of fighting, resettle Taranaki colonists, and to construct a military road. When conflict broke out in the Waikato the following year, this was rolled into a new loan authority for three millions to cover further war costs and bring more colonists to the North Island. ${ }^{84}$

The General Government failed to obtain a new imperial guarantee for any of its borrowings on terms that would be acceptable to it or the provinces, but even without this most of the money for the colonists would still have to be found in London. ${ }^{85}$ Almost immediately, this became impossible as far as the provinces were concerned unless they were prepared to accept deep discounts on the prices of their bonds. ${ }^{86}$ In

82 NZ AJHR, B-5, 1863, p. 16, Grey to Newcastle, 20 February 1863.

83 The Times, 20 December 1860, p. 6.

84 United Kingdom, Correspondence, Financial statement, 10 Nov 1863, pp. 254, $261-2$.

85 The negotiations for the guarantee can be followed in both British and colonial parliamentary papers.

86 Greater detail can be found in Attard, Free-trade Imperialism. 
October 1863, the Bank of New Zealand (BNZ) sold a first instalment of the Auckland loan at prices yielding a rate of interest to the buyers of about $5 \frac{3 / 4}{4}$ per cent. ${ }^{87}$ The Stock Exchange, however, declined to quote the bonds, choosing to treat the New Zealand provinces like any other colonial municipality. ${ }^{88}$ Effectively they became unmarketable as far as most investors were concerned. A few months later, the Secretary of the Union Bank, which was itself holding Canterbury debentures for sale in London, confirmed: 'there cannot be a doubt but that ... several circumstances operate most adversely to the general quotation of Provincial Securities on our Stock Exchange, which has never been accomplished even with Melbourne Corporation Bonds' ${ }^{89}$ When the BNZ offered a first tranche of an Otago half million loan in January 1864 priced to yield a similar return as the Auckland issue, the bank's failure was complete. The root of the difficulty was the Stock Exchange's mistrust of the credit of obscure provincial borrowers and agents like the BNZ. The Union's Secretary explained to the bank's general manager in the colonies:

87 Yields are calculated as gross yields to maturity for loans maturing at a fixed date, and running yields for Consols and drawing loans, after accrued interest has been deducted. For issue prices for New Zealand loans, Attard, Database; for Consols, average price as quoted in The Times. Fractions are based on contemporary conventions. London Metropolitan Archives: CLC/B/004/B/01/MS14600/027, f. 374, 9 Nov 1863.

89 ANZ: U/120/19, Saunders to McMullan, no. 907, 23 Feb 1864; emphasis in original. 
There must be a more discriminating knowledge of both the Colonies and the Banks in question, before it will be possible to place a just estimate on our Stock Exchange of the comparative values of different Debentures, whether for permanent holders or the daily operations of speculators - both argue that if $£ 500,000$ be excessive for Auckland, $£ 800,000$ appears excessive for Christchurch, \&c, \&c, and you see the treatment the Otago Loan has just experienced. $^{90}$

Towards the end of the year, one of the BNZ's creditors forced a sale of $£ 150,000$ of the Otago bonds. The discount was 20 per cent of the bonds' nominal value, raising the yield to 8 per cent. ${ }^{91}$ In twelve months, the premium on provincial debt over British Consols, the safest and most liquid security in London, had almost doubled from $2 \frac{1}{2}$ to $4 \frac{3}{4}$ per cent. Similar offers of Otago and Canterbury debentures in 1865 and 1867 respectively met similar fates. Loans for Southland and Hawkes Bay were never even advertised, the London agent of the latter observing in early 1867: 'never, even now when money is almost a drug at $2 \%$, have I received an offer approaching the Superintendent's minimum [price]' ${ }^{92}$ By contrast, between 1864 and 1867, the Crown Agents for the Colonies succeeded in bringing out the General Government's three millions loan in fits and starts, despite the colony's repeated financial and military embarrassments and frequent market disturbances. When the City's most

90 ANZ: U/120/19, Saunders to McMullan, no. 900, 25 Jan 1864.

91 ANZ: U/120/22, Saunders to McMullan, no. 976, 9 Nov 1864.

92 ANZ: U/119/6, Saunders to McMullen, no. 1183, 20 Feb 1867. 
prestigious merchant bank, N. M. Rothschild, successfully bid for the last instalment, the recovery of the colony's standing in London was complete. ${ }^{93}$

There had been many reasons for the colonists' troubles. ${ }^{94}$ Yet while the General Government's credit steadily recovered from its nadir in 1866, provincial debentures still could not be sold at acceptable prices. The Stock Exchange's aversion to minor colonial borrowers has already been noted. ${ }^{95}$ A large cloud also now hung over provincial finances because of the General Government's growing demands on the public purse, not least to cover the charges for its own increased borrowings. ${ }^{96}$ Only a month before the outbreak of the Taranaki fighting, Governor Gore Browne had anticipated 'a great increase of expenditure by the General Government ... and a consequently possible diminution of the proportion of Customs revenue calculated on by the Provincial authorities' ${ }^{97}$ In very different circumstances, the provinces' second approach to the London market had raised the same questions about credit-worthiness that had earlier exercised Whitehall's officials. Now, however, the entire basis of provincial finance since the Compact was suspect.

The General Government's solution was the same as a decade before. It was simply extended and made permanent. In 1867, as part of a general reform of colonial

93 The Times, 27 Nov 1867, p.10; most of the story of the three million loan can be followed in colonial sessional papers ordered to be printed during the sessions 1864 to 1866; see New Zealand, Index.

Attard, Free-trade Imperialism, p. 512.

95 ANZ: U/120/19, Saunders to McMullan, no. 907, 23 Feb 1864.

96 NZ, AJHR, B-3, 1864, memorandum, Hyde Harris, 26 July 1864.

97 TNA: PRO CO 209/153, f. 190, Gore Browne to Newcastle, no. 22, 27 Feb 1860. 
finances, the provinces' debts were secured on the colony's consolidated revenues and the charges deducted from the provincial shares of that revenue under the new fiscal arrangements. ${ }^{98}$ The General Government's credit was thus extended to all New Zealand's public loans. The holders of provincial bonds were invited to exchange them for the securities of a new consolidated issue, and debentures of the consolidated loan were also offered to investors in place of the unsold provincial bonds. By these means, all provincial borrowings up to 1867 would literally be absorbed into a unified 'national' debt. In return, the provinces would no longer be able to authorise new loans. By the end of $1868, £ 4,191,000$ of the New Zealand 'consols' were held by investors and just over half were a charge on the provincial shares of the revenue. ${ }^{99}$ William Fitzherbert, the colonial Treasurer, made the General Government's centralist ambitions absolutely clear when he originally explained them in the Assembly:

It [i.e. the General Government] takes still broader views, and is unwilling that the unity of the Colony should remain a mere idle name, and desires that the powerful combination expressed in that term should be made to yield its legitimate financial results, by putting in motion the vast power of a common credit, which is now frittered away and wasted by being exercised provincially. But in order that such results may be obtained, it is indispensable that the 
Government of the Colony should exist as a reality with large controlling powers. ${ }^{100}$

The logical corollary was not only that the General Government would in future undertake all public borrowing for the colony, but that it should also take charge of the development process itself. Julius Vogel foreshadowed this much when appointed colonial Treasurer in 1869 . It became reality a year later when he proposed a grand scheme for loan-financed railways, roads and immigration. Some of this was intended to consolidate the pastoralists' hold on their runs in the North Island, but the bulk of the railway expenditure would be in the south. ${ }^{101}$ Vogel originally anticipated that the provinces would cooperate in implementing the investment programme, but he was also adamant that 'if the existence of the present institutions of the country are inconsistent with the promotion of Public Works and Immigration and a choice must be made, I would infinitely prefer the total remodelling of those institutions' ${ }^{102}$ In reality many provinces already lacked the means to play their allotted parts and soon the General Government took over entirely. Deprived of their colonising functions, 'their utility was exhausted'. ${ }^{103}$

In the end, British capital may also have contributed to the provincial system's final abolition. The costs of supporting the weaker provinces remained a drag on the General Government. According to his biographer, in 1874 Vogel proposed to do

\footnotetext{
100 NZ, AJHR, B-1A, 1867, p. 6. Financial statement.

101 Arnold, New Zealand's Burning, pp. 24-26; Bassett, State in New Zealand, p. 59.

102 NZ, AJHR, B-2, 1870, p. 14. Financial statement.

103 Morrell, Provincial System, p. 228.
} 
away with the North Island provinces to improve the chances of the colony's next loan in London: 'one way of making it more attractive would be to present New Zealand as a united country, to show that the central government was in control, and

not constantly under pressure from the provincial governments of the North Island., ${ }^{104}$ Soon the proposal was extended to all the provinces. With only limited opposition, they disappeared in 1876.

Vogel had made good his pledge to 'remodel' the colony's institutions. But this had been inevitable as soon as even the most prosperous provinces were unable to borrow on the strength of their own credit and thereby failed as the colony's chief developmental agencies. Vogel was only completing a centralising process that had made a false start in 1857 but had become irreversible a decade later. As Edward Stafford originally recognised, and William Fitzherbert affirmed when announcing the new settlement of provincial finances in 1867 , successful development in colonial conditions required the exercise of 'the vast power of a common credit', which was only possible in New Zealand when 'the Government of the Colony should exist as a reality with large controlling powers.' Both the imperial authorities, who had been asked to guarantee the first of the colony's loans, and the London capital market, which was invited to tender for provincial securities without the benefit of one, had understood this all along. British financial interests came first and, if called for, colonial institutions would have to change to suit them.

104 Dalziel, Julius Vogel, p. 174. The pretext was the provinces' opposition to a forestry bill. 


\section{DEVELOPMENT, WARFARE AND THE COLONIAL STATE}

Two powerful settler imperatives were active in colonial New Zealand from the $1850 \mathrm{~s}$ through to the mid-1870s, each (to quote Belich again) contributing to 'the rise of the central state and its alter ego, the national debt': the imperative to colonise and create new societies as expressed by the pan-British ideology of 'settlerism', and the imperative to assert colonial sovereignty over indigenous people. ${ }^{105}$ The two were closely related and interacted most obviously in the settlers' dealings (including open warfare) with traditional occupiers over land. Nevertheless this article has argued that the drive to settle and develop created a distinct and separate dynamic in settler societies which favoured the growth of centralised states quite apart from the need to impose settler control over territory and people. Even though well into the 1880 s the central government was 'often surprisingly impotent in dealing with local and regional needs and crises' (an important caveat in any argument about 'centralisation'), Arnold affirms: ‘The centre's most significant decision making role lay in determining development priorities. ${ }^{, 06}$ Public borrowing for development meant that state formation was closely connected to the settler's involvement in metropolitan capital markets. The colonial state functioned, in part, to raise capital for developmental purposes; and if necessary the colonial state would be restructured in order to achieve this. New Zealand was no exception. ${ }^{107}$ It follows that the impact of

105 Belich, Making Peoples, p. 242.

106 Arnold, New Zealand's Burning, pp. 252-53.

107 For public borrowing as the New Zealand state's 'raison d'être' in the 1870s, see Fletcher, quoted in Arnold, New Zealand's Burning, p. 252. 
warfare on state formation and the rise of the public debt in New Zealand needs to be re-considered and viewed from a wider perspective.

There is no question that the costs of fighting and extending settler occupation in the North Island added enormously to colonial indebtedness during the $1860 \mathrm{~s}$, ratcheting it to a far higher level than it probably would otherwise have been. The borrowings of the General Government and two provinces most affected (Auckland and Taranaki) accounted for almost two-thirds of the increase of the national debt between 1860 and $1868 .{ }^{108}$ Ultimately, however, the impact of warfare was transient. In New Zealand, as in other settler societies, the underlying force driving the growth of indebtedness was the dynamic of colonial development played out with the blessing of imperial authority over several decades. As Figure 3 shows, the national debt's rise was a phenomenon of both the 1850 s and the 1860 s, interrupted only by the interval of tight restriction during Stafford's first ministry. The abortive attempt of the South Island provinces to initiate large-scale borrowing in the late 1850s and into the 1860 s was an expression of the basic continuity of the relationship between debt and development in settler society. Irrespective of warfare, the pressures to accelerate public investment throughout the colony would have caused the national debt to grow; only its speed is to be questioned. The 1860 s were, in fact, a difficult decade for all colonial borrowers in London. ${ }^{109}$ Warfare, in New Zealand's case, was simply an additional factor retarding the development process. Even so, by dint of heavy

108 General Government, $£ 3,574,700$; provincial, $£ 566,450$ (including provincial shares of the consolidated loan), NZ, AJHR, B-6, 1869.

109 See the examples of Canada and New South Wales in Piva, The Borrowing Process, ch. 8, and Lamb, Early overseas borrowing. 
discounts and eventual underwriting by the consolidated revenue, over two millions were raised for development purposes in New Zealand between 1860 and 1868, and the provincial share of the national debt recovered to 45 per cent, having fallen to just under 40 per cent a couple of years before (Appendix II).

Yet arguably the greatest impact of New Zealand's Wars on the development process was as a catalyst, accelerating changes to the system of government that were already necessary if the colony was to mobilise the large sums of British capital needed for public investment on any significant scale. Even if there had been no warfare during the $1860 \mathrm{~s}$, the provinces always lacked the credit, resources and capacity to move beyond purely local projects. Sooner or later the General Government would have had to assume responsibility as the leading development agency in the colony. As early as 1857 , external pressures had contributed to the first significant assertion of central control over provincial borrowing because of doubts over the provinces' ability to support new debt. The South Island's boom temporarily allayed these fears. But from 1860 the coincidence of warfare in the north with the attempt to launch an ambitious, but entirely uncoordinated, programme of public borrowing in the south forced the issue by drawing the London market's attention to the unstable foundations of provincial finance.

Ultimately the related problems of provincial finance and colonial development could only be resolved by a permanent change to the system of government, a centralisation of state powers intended also to make New Zealand credit acceptable to British capital. The colony's credentials as a borrower were refurbished as part of a new fiscal settlement between the General Government and the provinces. After 1867, with sole command of the public credit by a strengthened central state, the further 
Making the colonial state

growth of the national debt was assured. It remained only to strip the provinces of their development functions and, finally, abolish them altogether. 


\section{REFERENCES}

Adonis, A. (1991) The survival of the great estates: Henry, 4th Earl of Carnarvon and his dispositions in the eighteen-eighties. Historical Research, 64: 54-62.

Arnold, R. (1994) New Zealand's Burning: The Settlers' World in the mid 1880's (Wellington: Victoria University Press).

Attard, B. (2005) Database of Australasian government loans offered by public sale in London, 1857-1914 [computer file] (UK Data Archive, distributor) SN 5222.

Attard, B. (2007) From Free-trade imperialism to structural power: New Zealand and the capital market, 1856-68. Journal of Imperial \& Commonwealth History, 35: $505-27$.

Attard, B. (forthcoming). Wakefieldian investment and the birth of new societies, c. 1830 to 1930. In Christopher Lloyd, Jacob Metzer and Richard Sutch eds. Settler Economies in World History (Leiden: Brill).

Australia \& New Zealand Banking Group Limited, Group Archive, Melbourne (ANZ). U/7/5, Union Bank of Australia, Board Minutes, 1855-58.

ANZ. U/7/6, Union Bank of Australia, Board Minutes, 1858-60.

ANZ, U/10/11, Union Bank of Australia, Committee Minutes, 1856-58.

ANZ. U/102/5, Union Bank of Australia, Inspector's London Letter Books, 1858-59.

ANZ. U/103/2, Union Bank of Australia, Inspector's Letters [Inward], 1860-61.

ANZ. U/119/6, Union Bank of Australia, Secretary's Letters outward to General Manager, March 1866-May 1867.

ANZ. U/120/7, Union Bank of Australia, Manager London/Secretary's Letters inward to General Manager, 1856. 
ANZ. U/120/8, Union Bank of Australia, Manager London/Secretary's Letters inward to General Manager, 1857.

ANZ. U/120/13, Union Bank of Australia, Manager London/Secretary's Letters inward to General Manager, Jan-June 1861.

ANZ. U/120/14, Union Bank of Australia, Manager London/Secretary's Letters inward to General Manager, July-Dec 1861.

ANZ. U/120/19, Union Bank of Australia, Manager London/Secretary's Letters inward to General Manager, Jan-March 1864.

ANZ. U/120/22, Union Bank of Australia, Manager London/Secretary's Letters inward to General Manager, Oct-Dec1864.

Ballantyne, T. (2009) The state, politics and power, 1769-1893. In: G. Byrnes, ed. The New Oxford History of New Zealand (South Melbourne: Oxford University Press), pp. 99-124.

Bassett, M. (1998) The State in New Zealand, 1840-1984: Socialism without Doctrines? (Auckland: Auckland University Press).

Belich, J. (1996) Making Peoples: A History of New Zealanders from Polynesian Settlement to the End of the Nineteenth Century (Auckland: Allen Lane).

Belich, J. (2001) Paradise Reforged: A History of the New Zealanders from the 1880 s to the Year 2000 (Auckland: Allen Lane).

Belich, J. (2009) Replenishing the Earth: The Settler Revolution and the Rise of the Anglo-World, 1783-1939 (Oxford: Oxford University Press).

Belich, J. (2010), How much did institutions matter? Cloning Britain in New Zealand. In J.P. Greene ed. Exclusionary Empire: English Liberty Overseas, 1600-1900 (Cambridge: Cambridge University Press), pp. 248-68.

Briggs, A. (1979) The Age of Improvement, 1783-1867 (London: Longman). 
Burroughs, P. (1967) Britain and Australia 1831-1855: A Study in Imperial Relations and Crown Lands Administration (Oxford: Clarendon Press).

Butlin, N. G. (1959) 'Colonial Socialism in Australia, 1860-1900’. In H.G.J. Aitken ed. The State and Economic Growth (New York: Social Science Research Council), pp. 26-78.

Butlin, N. G. (1964) Investment in Australian Economic Development 1861-1900 (Cambridge: Cambridge University Press).

Butlin, S. J. (1961) Australia and New Zealand Bank: The Bank of Australasia and the Union Bank of Australia Limited, 1828-1951 (Melbourne: Longmans).

Cain, P. J., \& Hopkins, A. G. (2002) British Imperialism: 1688-2000, 2nd ed. (Harlow: Longman).

Cassis, Y. (2006) Capitals of Capital: A History of International Financial Centres, 1780-2005 (Cambridge: Cambridge University Press).

Cortes Condé, R. (2009) The Political Economy of Argentina in the Twentieth Century (Cambridge: Cambridge University Press).

Cottrell, P. L. (1975) British Overseas Investment in the Nineteenth Century (London and Basingstoke: Macmillan).

Dalziel, R. (1992) The politics of settlement. In: G. W. Rice, ed. The Oxford History of New Zealand, 2nd ed. (Auckland: Oxford University Press), pp. 87-111.

Dalziel, R. (1986) Julius Vogel: Business Politician (Auckland: Auckland University Press).

Gardner, W. J. (1992) A colonial economy. In: G. W. Rice, ed. The Oxford History of New Zealand, 2nd ed. (Auckland: Oxford University Press), pp. 57-86.

Hawke, G. R. (1985) The Making of New Zealand: An Economic History (Cambridge: Cambridge University Press). 
Hensley, G. A. (1971) Canterbury, 1853-7. In: W. J. Gardner, ed. A History of Canterbury Vol. 2 (Christchurch: Canterbury Centennial Historical and Library Committee and Whitcombe and Tombs), pp. 3-76.

Hopkins, A. G. (1999) Back to the future: From national history to imperial history. Past \& Present, 164: 198-243.

Jenks, L. H. (1927) The Migration of British Capital to 1875 (New York: Knopf).

Lamb, P. N. (1964) Early overseas borrowing by the New South Wales Government. Business Archives and History, 4: 44-62.

London Metropolitan Archives. CLC/B/004/B/01/MS14600/027, General Purposes Committee minutes [London Stock Exchange], April 1862-Jan 1864.

Lyttelton Times, 28 March 1860, p. 4.

McAloon, J. (2009) The New Zealand Economy, 1792-1914. In: G. Byrnes, ed. The New Oxford History of New Zealand (South Melbourne: Oxford University Press), pp. 197-218.

Marichal, C. (1989) A Century of Debt Crises in Latin America: From Independence to the Great Depression, 1820-1930 (Princeton: Princeton University Press).

Mein Smith, P. (2005) A Concise History of New Zealand (Cambridge: Cambridge University Press).

Morrell, W. P. (1964) The Provincial System in New Zealand 1852-76, 2nd ed. (Christchurch: Whitcombe and Tombs).

New Zealand. Parliament (1915) Index to the Appendices to the Journals of the Legislative Council and House of Representatives of New Zealand, 1854 to 1913 (Wellington: Parliament). 
New Zealand. Parliament. House of Representatives (NZ) Votes and Proceedings of the House of Representatives, 1854, session 1. Report of the Committee of the House of Representatives on the Public Debts of New Zealand.

NZ. Appendix to the Journals of the House of Representatives (AJHR), B-5, 1858.

Correspondence Relative to the New Zealand Loan of $£ 500,000$.

NZ. AJHR, B-8, 1861. Papers relative to the apportionment of the public debt of the provinces of Wellington and Hawke's Bay.

NZ, AJHR, B-1, 1862, Finance accounts of the General Government of New Zealand, $1860-61$.

NZ. AJHR, B-5, 1863. Correspondence relative to provincial loans.

NZ. AJHR, B-7, 1863. Return of all the sums authorised to be borrowed by the General and Provincial Governments of New Zealand.

NZ. AJHR, B-3, 1864. Further papers relative to provincial loans.

NZ. AJHR, B-6, 1866. Financial statement by the Hon. The Colonial Treasurer.

NZ. AJHR, B-1A, 1867. Financial statement by the Hon. The Colonial Treasurer.

NZ. AJHR. A-10, 1868. Correspondence relative to the payment of the Nelson and Marlborough provincial debts.

NZ. AJHR, B-6, 1868. Return of ordinances authorising provincial loans.

NZ. AJHR, B-6, 1869. Return of the total liability of the Colony, as well as the several Provinces, on account of existing loans.

NZ. AJHR, B-2, 1870. Financial statement by the Hon. The Colonial Treasurer. Otago Witness, 1859-61.

Otago. Provincial Council (Otago), Appendix to Votes and Proceedings (AV\&P), session IX, 1860, pp. xvi-Xx. Correspondence respecting loan for immigration purposes. 
Otago. $A V \& P$, session XVII, 1863, p. iii. Return of debentures issued by Provincial Government.

Parsonson, A. (1992) The challenge to Mana Māori. In: G. W. Rice, ed. The Oxford History of New Zealand, 2nd ed. (Auckland: Oxford University Press), pp. $167-198$.

Piva, M. J. (1992) The Borrowing Process: Public Finance in the Province of Canada, 1840-1867 (Ottawa: University of Ottawa Press).

Platt, D. C. M., and Adelman, J. (1990) London merchant bankers in the first phase of heavy borrowing: the grand trunk railway of Canada. Journal of Imperial and Commonwealth History, 18: 208-227.

Pritchard, M. F. L. (1970) An Economic History of New Zealand to 1939 (Auckland: Collins).

Scotter, W. H. (1971) Canterbury, 1857-68. In W. J. Gardner, ed. A History of Canterbury Vol. 2 (Christchurch: Canterbury Centennial Historical and Library Committee and Whitcombe \& Tombs), pp. 77-248

Simkin, C. G. F. (1951) The Instability of a Dependent Economy (Oxford: Oxford University Press).

Simmonds, P. L. (1863) Fenn's Compendium of the English and Foreign Funds, 8th ed. (London: Effingham).

Sorrenson, M. P. K. (1992) Māori and Pakeha. In: G. W. Rice, ed. The Oxford History of New Zealand, 2nd ed. (Auckland: Oxford University Press), pp. 141-166. South Australia. Parliament. Proceedings of the Parliament of South Australia, with copies of the documents ordered to be printed, no. 211, 1873. Report of the select committee of the House of Assembly on Consolidated Loan Bill; together with minutes of evidence and appendix. 
Statistics of New Zealand, 1862-68, 1870.

Stone, R. C. J. (2010) Brown, William - biography. The Dictionary of New Zealand Biography. Te Ara - The Encyclopedia of New Zealand. [Accessed 13 Sept 2011]. Available from URL:

http://www.TeAra.govt.nz/en/biographies/1b37/1.

The Times, 1857, 1860-61, 1867.

The National Archives of the UK (TNA). Public Record Office (PRO) CO 209/135,

Colonial Office and Predecessor: New Zealand Original Correspondence, Despatches, Jan-Apr.1856

TNA. PRO CO 209/136, Colonial Office and Predecessor: New Zealand Original Correspondence, Despatches, May-June 1856.

TNA. PRO CO 209/141, Colonial Office and Predecessor: New Zealand Original Correspondence, Despatches, Jan-June 1857.

TNA. PRO CO 209/148, Colonial Office and Predecessor: New Zealand Original Correspondence, Offices, 1858.

TNA. PRO CO 209/149, Colonial Office and Predecessor: New Zealand Original Correspondence, Individuals, 1858.

TNA. PRO CO 209/152, Colonial Office and Predecessor: New Zealand Original Correspondence, Offices and Individuals, 1859.

TNA. PRO CO 209/153, Colonial Office and Predecessor: New Zealand Original Correspondence, Despatches, Jan-April 1860.

TNA. PRO CO 209/157, Colonial Office and Predecessor: New Zealand Original Correspondence, Despatches, Dec 1860.

TNA. PRO CO 209/172, Colonial Office and Predecessor: New Zealand Original Correspondence, Despatches, Jan-April 1863 
United Kingdom. Parliament. Resolution adopted in New Zealand House of Representatives, with reference to Guarantee of Loan to be solicited from British Legislature, July 1856, No. 296 (1857-58).

United Kingdom. Parliament. Correspondence between Governor Sir G. Grey and Colonial Office relating to Policy of Confiscation adopted by New Zealand Legislature, No, 326 (1864).

Weaver, J. C. (1999) Frontiers into assets: the social construction of property in New Zealand, 1840-65. Journal of Imperial and Commonwealth History, 27: 17-54.

Wilkins, M. (1989) The History of Foreign Investment in the United States to 1914. (Cambridge, Mass.: Harvard University Press). 
APPENDIX I

NEW ZEALAND PUBLIC DEBT, 1853-61

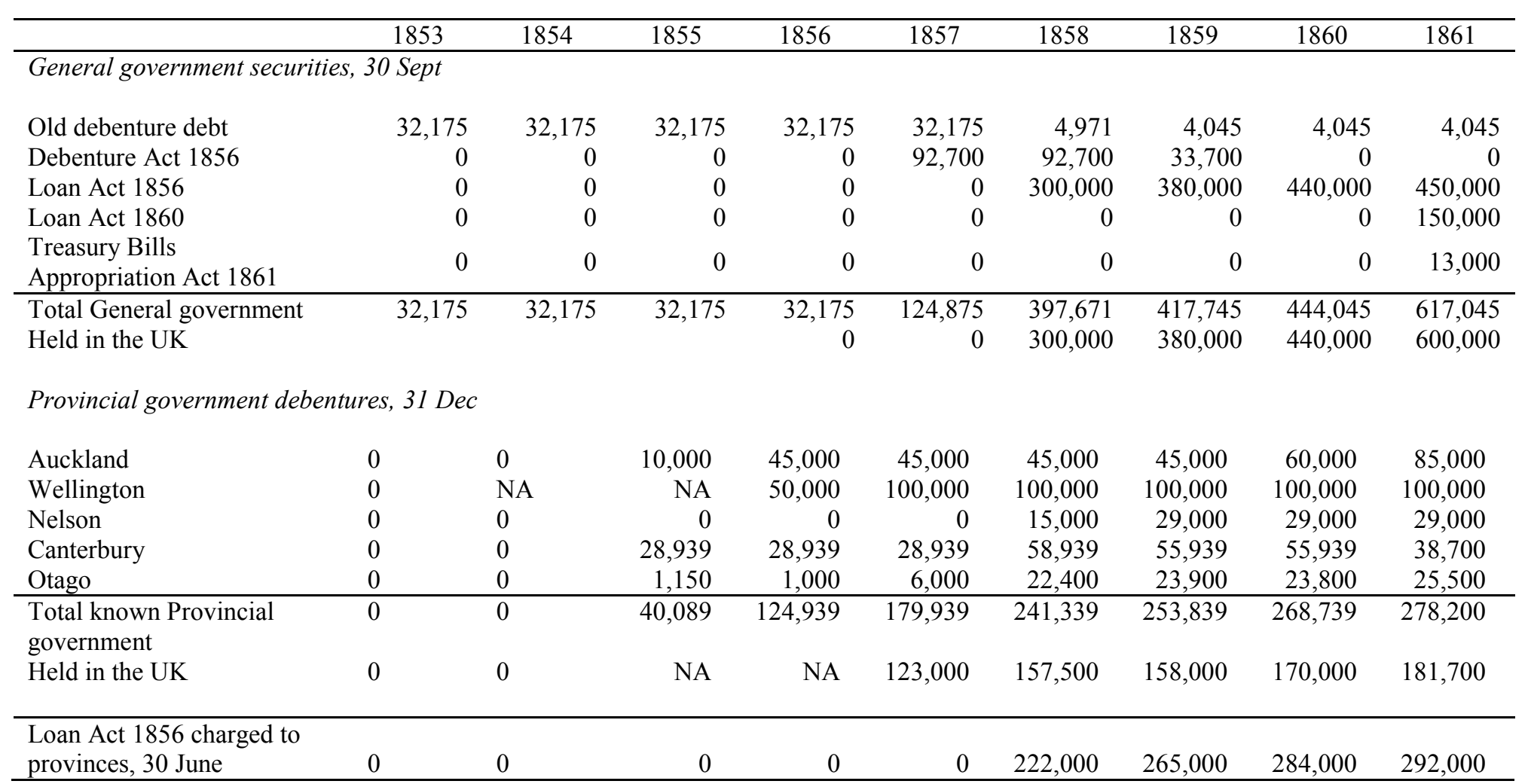




\section{Notes and Sources}

General Government securities

The statistics have been derived from Financial Statements and Finance Accounts in NZ, Votes and Proceedings and AJHR, 1854-62 (see New Zealand, Index, p. 190; indexed as 'public accounts'). The total for the 'old debenture debt' in 1853 has been taken from Votes and Proceedings, 1854, Report, p. 235a (sic) as being more consistent with subsequent statements of redemption and outstanding balances.

\section{Provincial government securities}

The statistics have been derived from information of authorisations and known issues and sales as explained below. NZ, $A J H R, \mathrm{~B}-7,1863$ has been used as a benchmark.

\section{Auckland}

The $£ 10,000$ debentures sold in Auckland in October 1855 (Provincial Government Gazette, vol. 3, no. 32, 9 Nov 1855; enclosure in TNA: PRO CO $209 / 135$, f. 136) are included for that year. The $£ 45,000$ debentures, payable in May 1865, issued under the Loan Act of April 1856 are assumed to have been sold in 1856. All the City of Auckland debentures are assumed sold during 1861, with the balance not offered in London having been taken up in the colony, see The Times, 31 May 1860, p. 8 and 12 June 1860, p. 8. For the Auckland Harbour Loan: The Times, 4 Nov 1861, p. 4; ANZ: U/120/14, Secretary to Manager, Auckland, 23 Nov 1861. 


\section{Wellington}

'Some few thousands' of the debentures authorised by Loan Ordinance in July 1854 (the 'Gladstone Loan') were sold during 1854-55 and the balance taken by the merchant John Gladstone \& Co. in 1856 (NZ, AJHR, B-8, 1861, no. 6, Featherstone to Colonial Secretary, 12 Dec 1859, p. 5). They are only included from that year. Only $£ 50,000$ of the two loans authorised in 1857 were sold because of the disallowance of one ordinance (The Times, 30 June 1857, p. 4; ANZ: U/10/11, 19 Aug 1857; U/120/8, Saunders to Superintendent, 16 Dec 1857).

\section{Nelson}

$£ 15,000$ debentures authorised by the Act of 1858 were sold in Sydney that year; I have assumed these were debentures nos. 1 to 150 , due 1 July 1868, 50 of which were redeemed by the Crown Agents in London (ANZ: U/102/5, McMullen to Cummins, no. 259, 10 June 1858; South Australia (SA), Proceedings, no. 211, 1872, p. 63). I have assumed the balance of the loan, $£ 14,000$ due 1869 (including the $£ 700$ held in New Zealand and $£ 1,000$ not converted in 1868) was sold in the following year, SA, Proceedings, no. 211, 1872, pp. 54, 56; NZ, AJHR, A-10, 1868, nos. 15, 20-21.

\section{Canterbury}

In November 1855, the Superintendent reported that $£ 28,925$ debentures authorised by the Canterbury Association Ordinance had been issued, $£ 18,000$ of which Henry Sewell was to take to England (ANZ: U/120/7, Fitzgerald to Directors, Nov 1855 [sic], enclosure with Saunders to McDonald, no. 395, 21 
April 1861). I have assumed that the full amount that was authorised (i.e. $£ 28,939$ ) was outstanding at the end of that year. In 1859, the UBA received $£ 3,000$ to pay-off debenture nos 1 to 199 , which I have assumed occurred that year. No other debentures had been redeemed by February 1861 (ANZ: U/120/13, Secretary to Selfe, 6 Feb 1861; Selfe to Secretary, UBA, 7 Feb 1861). $£ 8,700$ of the debentures were still outstanding in December 1862; without other information, I have assumed this also was the amount outstanding twelve months before (Statistics of New Zealand 1862, Table 36). The $£ 30,000$ debentures authorised by the 1856 Loan Ordinance were sold privately in July 1858 (ANZ: U/7/6, 24 July 1858).

\section{Otago}

Otago, Appendix, 1863.

\section{Taranaki}

Debentures issued under the province's Loan Ordinance, 1857 (£2,300 were authorised) have been excluded because of insufficient information; $£ 300$ were outstanding in December 1862 (Statistics of New Zealand 1862, Table 36).

Loan Act 1856 charged to provinces: Finance Accounts, NZ, AJPH, 1860-62 (see New Zealand, Index, p. 190; indexed as 'public accounts'). 


\section{APPENDIX II}

NEW ZEALAND PUBLIC DEBT, 1862-69

\begin{tabular}{llrlrrr}
\hline & $\begin{array}{l}\text { General } \\
\text { government }\end{array}$ & $\begin{array}{l}\text { Provincial } \\
\text { securities }\end{array}$ & $\begin{array}{l}\text { Debt } \\
\text { charged to } \\
\text { General } \\
\text { Government }\end{array}$ & $\begin{array}{l}\text { Debt } \\
\text { charged to } \\
\text { provinces }\end{array}$ & $\begin{array}{l}\text { Total NZ } \\
\text { debt }\end{array}$ & $\begin{array}{l}\text { Provincial } \\
\text { share of } \\
\text { total, \% }\end{array}$ \\
\hline 1862 & 600,316 & 276,000 & 285,316 & 591,000 & 876,316 & 67 \\
1863 & 600,316 & 549,750 & 285,316 & 864,750 & $1,150,066$ & 75 \\
1864 & $1,450,316$ & 769,450 & $1,135,316$ & $1,084,450$ & $2,219,766$ & 49 \\
1865 & $3,017,282$ & $1,351,400$ & $2,673,282$ & $1,695,400$ & $4,368,682$ & 39 \\
1866 & $3,518,054$ & $1,614,675$ & $3,174,054$ & $1,958,675$ & $5,132,729$ & 38 \\
1867 & $3,848,844$ & $1,932,350$ & $3,504,844$ & $2,276,350$ & $5,781,194$ & 39 \\
1868 & $6,639,144$ & 539,000 & $3,916,544$ & $3,261,600$ & $7,178,144$ & 45 \\
\hline
\end{tabular}

Notes: Totals have been are adjusted to include Auckland and old debentures omitted from early issues of Statistics of New Zealand, and to exclude Southland and Canterbury debentures issued but not sold. Debt charged to the provinces includes the provincial shares of the Guaranteed Loan of 1856 (calculated from Finance Accounts excluding the amounts raised for Taranaki) and the Consolidated Loan of 1867 . The provincial shares of the Loan of 1863 (the 'Three Million Loan)—which, in June 1866 , amounted to $£ 244,254$ - have not been included because this liability was removed in 1867 as part of the Stafford ministry's financial reforms that year (Morrell, Provincial System, p. 185).

Sources: Statistics of New Zealand, 1862-68; NZ, AJHR, B-6, 1866, p. 11; Finance Accounts, AJHR, 1863-65 (see New Zealand, Index, p. 190; indexed as 'public accounts'. 


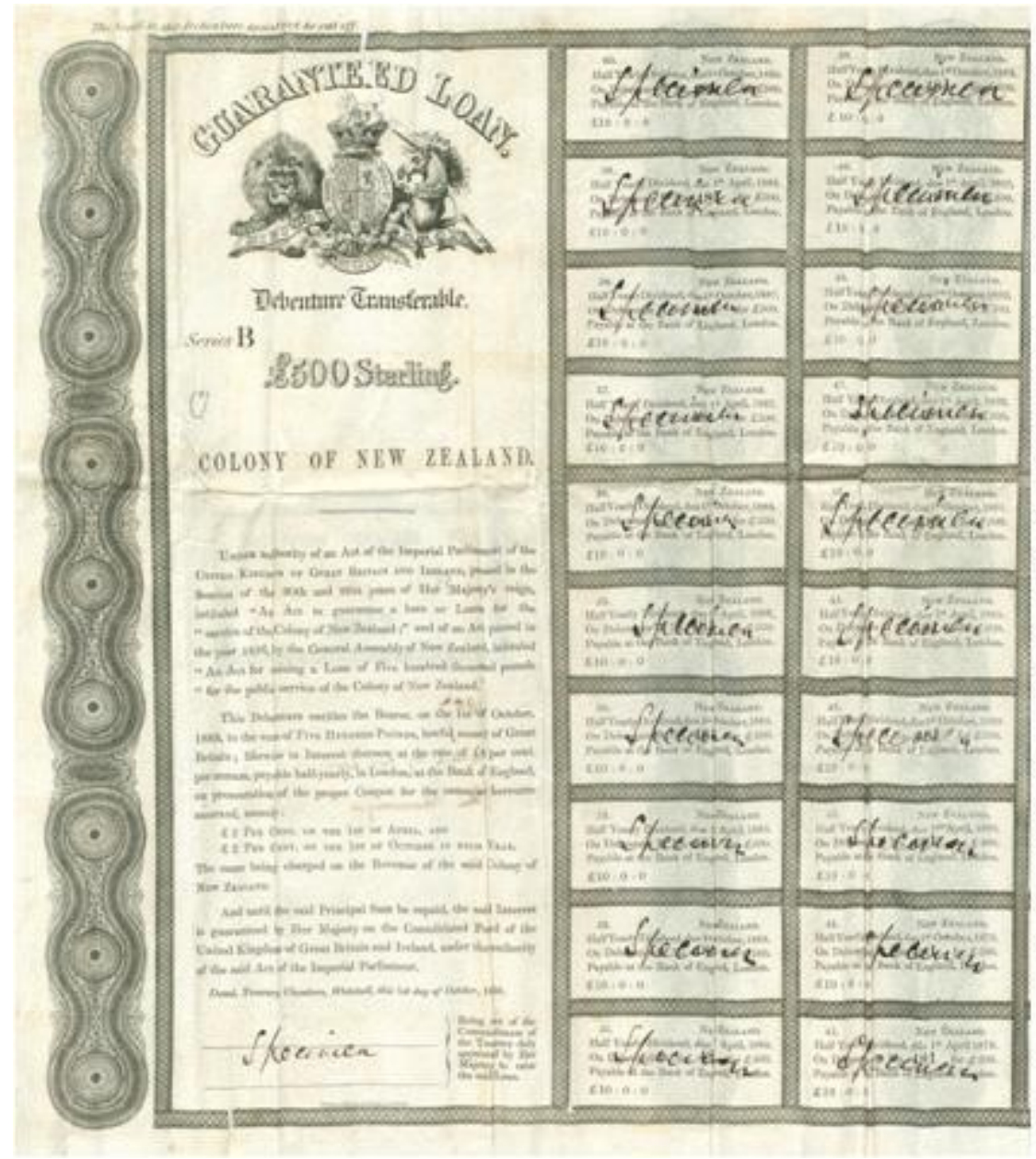

Figure 3. New Zealand Guaranteed Loan, Specimen Debenture, Series B, £500, October 1858

Source: TNA: T1/6109B

[NB High resolution TIF will be supplied on disk] 


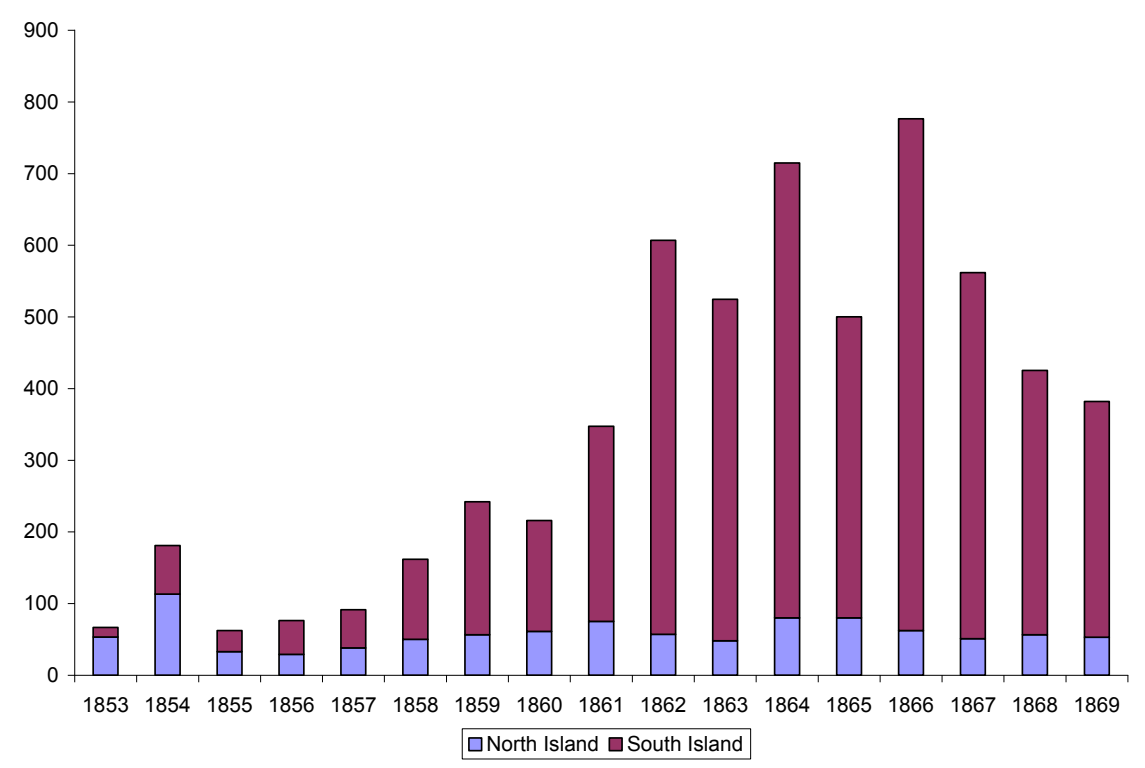

Figure 2. Territorial Revenues, 1853-69, £000

Source: Statistics of New Zealand, 1870, table 31. 


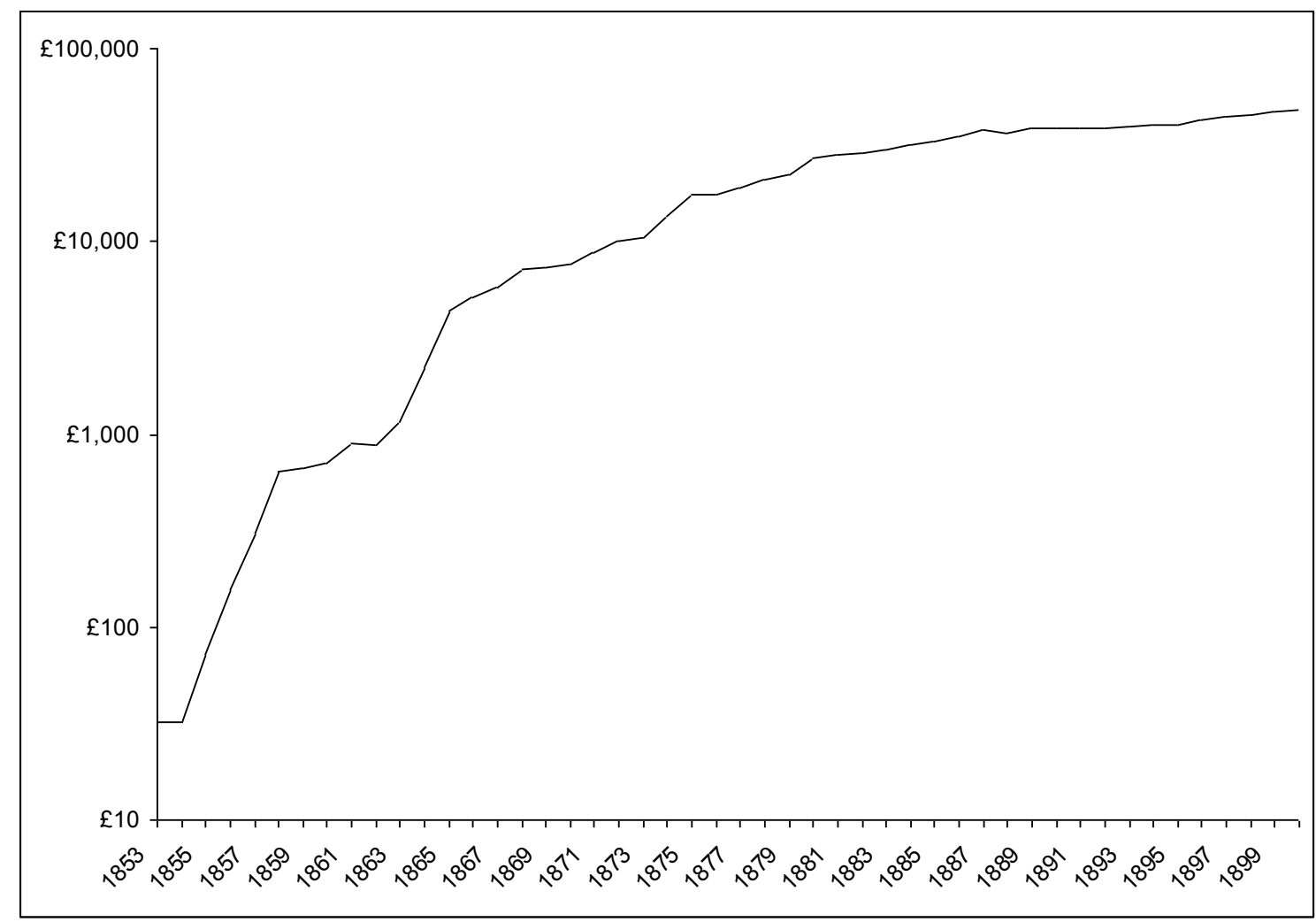

Figure 3. New Zealand Public Debt, 1853-1900, semi-log scale, (£000)

Notes: General Government and provincial totals, 1853-61 are summed. The totals for 1862-69 are at 31 December; 30 June thereafter.

Sources: as for appendices 1 and 2, plus NZ, AJPH, Finance Statements, 1870-1900 (see New Zealand, Index, p. 190, indexed as 'public accounts'). 